\title{
ANALISIS PENGARUH LUBANG PADA BALOK KASTELA TERHADAP DEFLEKSI DAN LATERAL-TORSIONAL BUCKLING DENGAN METODE ELEMEN HINGGA
}

\author{
Royki $^{1}$ dan Leo S. Tedianto ${ }^{2}$ \\ ${ }^{1}$ Program Studi Sarjana Teknik Sipil, Universitas Tarumanagara, Jl. Letjen S. Parman No. 1 Jakarta \\ Email: royki88@yahoo.com \\ ${ }^{2}$ Program Studi Sarjana Teknik Sipil, Universitas Tarumanagara, Jl. Letjen S. Parman No. 1 Jakarta \\ Email: leotedi@gmail.com
}

\begin{abstract}
ABSTRAK
Balok kastela merupakan sebuah profil baja yang dibentuk dengan cara memotong profil baja berbentuk I lalu melakukan pengelasan untuk mendapatkan sebuah profil yang memiliki sifat mekanis yang lebih baik. Pada beberapa kasus, bukaan atau lubang tersebut ditutup baik untuk mencapai tujuan estetika maupun kekuatan. Serangkaian ujicoba dilakukan dengan metode elemen hingga menggunakan program Abaqus untuk menemukan hubungan antara penutupan lubang bukaan terhadap kapasitas beban yang dapat dipikul dan defleksi yang terjadi. Hasil percobaan menunjukkan adanya perubahan terhadap defleksi yang terjadi dan peningkatan terhadap kapasitas beban yang dapat dipikul pada kondisi tekuk torsi-lateral seiring dengan dilakukannya penutupan lubang pada balok kastela.
\end{abstract}

Kata kunci: Balok kastela, bukaan, lubang, metode elemen hingga, defleksi, tekuk torsi-lateral, kapasitas beban.

\section{PENDAHULUAN}

\section{Latar Belakang}

Balok kastela (castellated beam) merupakan sebuah balok dari profil baja yang dibuat dengan cara melakukan pemotongan terhadap sebuah profil baja I-WF (I-shaped Wide Flange) kemudian melakukan pengelasan untuk menggabungkan kedua bagian tersebut. Profil kastela yang dihasilkan memiliki sifat mekanis yang lebih baik bila dibandingkan dengan profil baja semula.

Dalam proses desain, seringkali efek dari tekuk torsi lateral (lateral-torsional buckling) diabaikan karena pada umumnya balok kastela digunakan bersamaan dengan metal deck dan/atau balok lainnya dengan konfigurasi sedemikian rupa sehingga memberikan tahanan lateral yang cukup untuk mencegah pengaruh torsi lateral dan meminimalkan defleksi lateral. Namun, apabila metal deck tidak digunakan, maka pengaruh torsi lateral tidak dapat diasumsikan ditahan langsung oleh pelat beton, begitu juga apabila balok lainnya tidak memberikan tahanan yang cukup.

Lubang pada balok kastela juga dapat ditutup kembali untuk tujuan estetika ataupun kekuatan karena kemampuan penampang tersebut untuk memikul beban akan meningkat apabila lubang pada penampang tersebut ditutup. Lubang dapat ditutup kembali dengan cara melakukan pengelasan pada pelat baja yang telah dipotong dengan ukuran yang sama dengan lubang tersebut.

Atas dasar pertimbangan tersebut, maka disusunlah penelitian ini yang akan membahas mengenai pengaruh bukaan lubang terhadap defleksi lateral dan lateral-torsional buckling pada balok kastela. Analisis yang akan dilakukan untuk mengetahui besarnya pengaruh bukaan lubang terhadap balok kastela tersebut akan dilakukan dengan bantuan program Abaqus. Abaqus merupakan program analisis yang menggunakan prinsip Analisis Elemen Hingga (Finite Element Analysis, FEA) untuk menyelesaikan berbagai permasalahan dalam bidang analisis struktur.

Penelitian ini membatasi penggunaan profil pada ukuran balok kastela dengan ukuran 150x450 dengan lubang honeycomb sesuai dengan spesifikasi PT. Gunung Garuda. Material yang digunakan adalah SS400 yang mengacu pada standar JIS G 3101. Tegangan sisa (residual stress) tidak dipertimbangkan pada penelitian ini. Weld joint dianggap bersifat rigid sekali sehingga kegagalan pada sambungan las balok kastela tidak dipertimbangkan. Panjang bentang juga dibatasi pada kondisi yang akan menyebabkan elastic lateral-torsional buckling, yaitu lebih tinggi dari $L_{r}$, yaitu batasan panjang bentang yang tidak ditahan secara lateral pada kondisi batas inelastic lateral-torsional buckling. 


\section{DASAR TEORI}

\section{Regangan dan Tegangan Hot-Rolled Steel}

Penelitian ini menggunakan material SS400 sebagai material penyusun balok kastela. SS400 merupakan material baja yang mengacu pada standar JIS G 3101. SS400 merupakan baja karbon dengan komposisi karbon, silikon, dan mangan yang tidak ditentukan, fosfor di bawah $0.05 \%$, dan sulfur di bawah $0.05 \%$. Huruf " $S S$ " memiliki arti Structural Steel, dan 400 menyatakan tensile strength sebesar $400 \mathrm{~N} / \mathrm{mm}^{2}$. SS400 memiliki titik leleh sebesar 245 $\mathrm{N} / \mathrm{mm}^{2}$ untuk ketebalan $16 \mathrm{~mm}$ ke bawah dan $235 \mathrm{~N} / \mathrm{mm}^{2}$ untuk ketebalan di atas $16 \mathrm{~mm}$. Elongasi minimum dari material SS400 untuk ketebalan $5 \mathrm{~mm}$ ke bawah adalah sebesar 21\%, untuk ketebalan antara 5 hingga 16 mm adalah sebesar $17 \%$, dan untuk ketebalan di atas $16 \mathrm{~mm}$ adalah sebesar $21 \%$.

Perhitungan untuk nilai regangan dan tegangan untuk hot-rolled steel (baja gilas panas) dilakukan berdasarkan hasil penelitian yang telah dilakukan oleh Xiang Yun dan Leroy Gardner pada tahun 2017 dengan judul "Stress-Strain Curves for Hot-Rolled Steel" yang diterbitkan pada Journal of Constructional Steel Research Volume 133 dengan DOI 10.1016/j.jcsr.2017.01.024. Terdapat dua model diagram regangan-tegangan yang dapat digunakan berdasarkan jurnal tersebut, yaitu quad-linear model dan bilinear+strain hardening model (nonlinear model). Pada penelitian ini digunakan quad-linear model yang lebih sederhana.

\section{Quad-Linear Model}

Quad-Linear model merupakan model yang mendefinisikan perilaku regangan terhadap tegangan baja sebagai persamaan empat garis linear yang dapat dilihat pada Gambar 1.

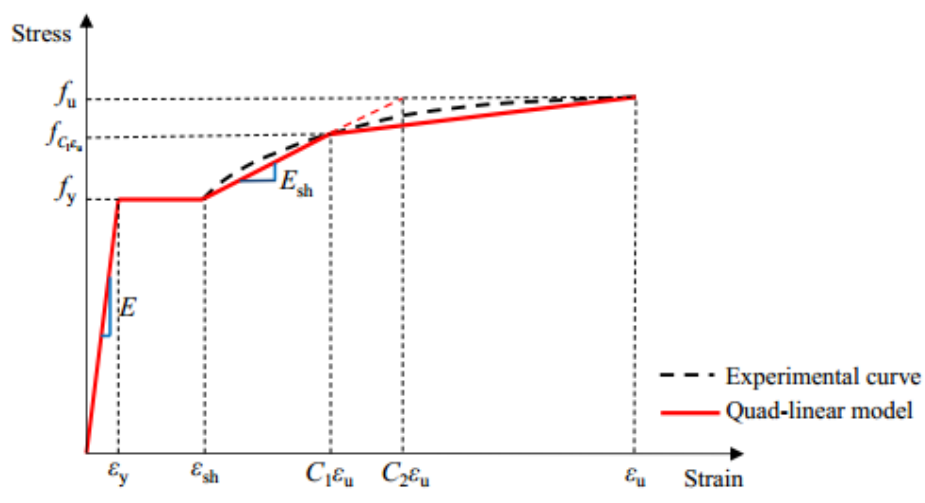

Gambar 1. Quad-Linear Model untuk Diagram Regangan Tegangan

Perhitungan yang dilakukan untuk memperoleh hasil sesuai dengan Gambar 1 menggunakan persamaan berikut:

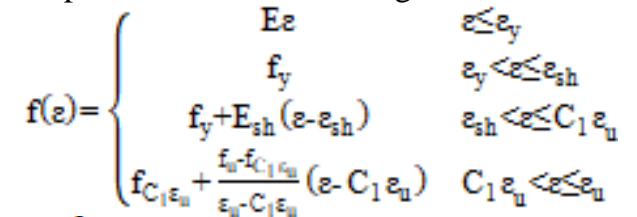

$$
\begin{aligned}
& e_{\mathrm{u}}=0.6\left(1-\frac{\mathrm{f}_{\mathrm{V}}}{\mathrm{f}_{\mathrm{u}}}\right), e_{\mathrm{u}} \geq 0.06 \text { untuk baja gilas panas (hot-rolled) } \\
& \varepsilon_{\text {sh }}=0.1 \frac{f_{Y}}{f_{i}}-0.055,0.015 \leq \varepsilon_{\text {gh }} \leq 0.03
\end{aligned}
$$

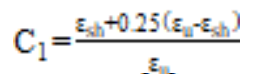

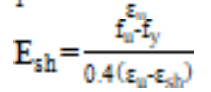

dengan $\mathrm{C}_{1}=$ konstanta yang digunakan untuk melakukan perhitungan tegangan material baja, $\mathrm{E}=$ modulus elastisitas, $\mathrm{E}_{\mathrm{hh}}=$ modulus elastisitas ketika material mengalami fenomena strain hardening, $\varepsilon=$ regangan total pada material, $\varepsilon_{\mathrm{sh}}=$ regangan total ketika material mengalami fenomena strain hardening, $\varepsilon_{\mathrm{u}}=$ regangan ultimate yang dapat dicapai oleh material, $\mathrm{f}_{\mathrm{C}: \mathrm{g}}=$ tegangan pada penampang pada titik regangan tertentu, $\mathrm{f}_{\mathrm{y}}=$ tegangan leleh material dan $f_{u}=$ tegangan ultimate material. 


\section{Batas Camber dan Sweep pada Balok Baja}

Peraturan ASTM A-6M-07 menyatakan batasan yang diizinkan untuk besarnya camber dan sweep sebesar $L_{1000}$ dengan $L$ merupakan panjang bentang dari balok baja yang ditinjau. Gambar 2 akan menjelaskan mengenai camber dan sweep.

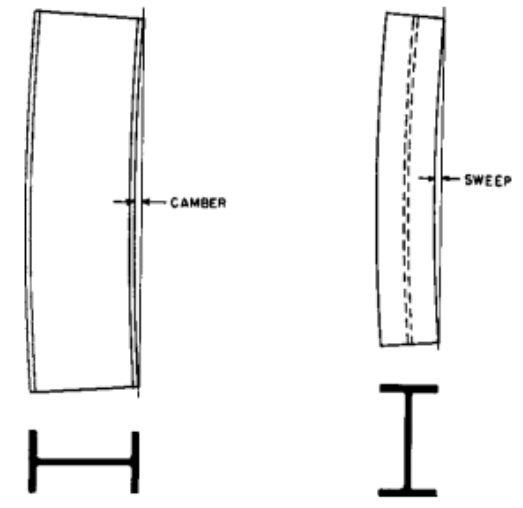

Gambar 2. Camber dan Sweep pada Balok Baja Mengacu pada ASTM A-6M-07

\section{Analisis Elemen Hingga}

Analisis yang dilakukan pada penelitian ini menggunakan program Abaqus dengan Standard/Explicit Model. Jenis elemen yang digunakan merupakan elemen solid 3D dengan tipe C3D8 dengan second-order accuracy. C3D8 merupakan first-order element dengan bentuk hexahedron yang memiliki 8 node.

Model analisis yang digunakan pada analisis ini merupakan sebuah balok kastela dengan lubang bukaan berbentuk honeycomb dengan ukuran yang dideskripsikan pada Tabel 1 dan Gambar 2.
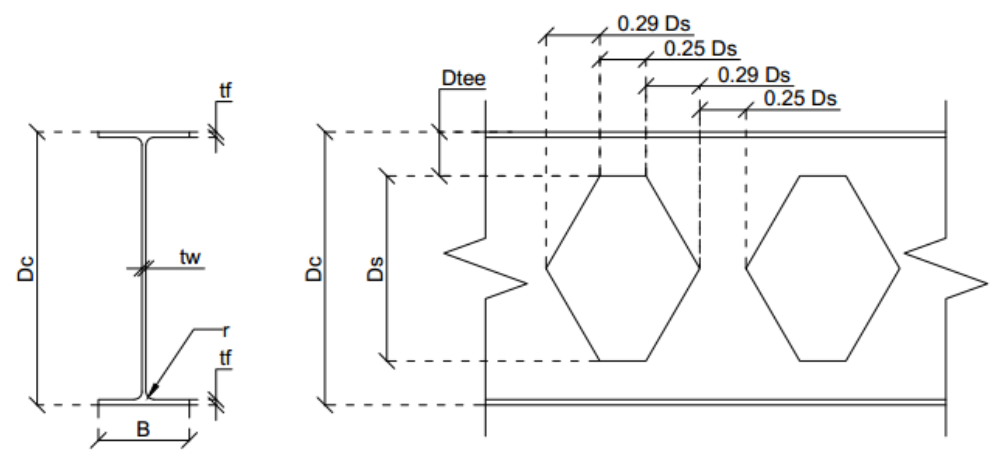

Gambar 2. Spesifikasi Ukuran Balok Kastela dan Lubang Bukaan Menurut PT. Gunung Garuda

Tabel 1. Ukuran Balok Kastela Honeycomb 450x150

\begin{tabular}{|c|c|}
\hline $\mathrm{B}(\mathrm{mm})$ & 150 \\
\hline $\mathrm{Dc}(\mathrm{mm})$ & 450 \\
\hline Ds $(\mathrm{mm})$ & 305 \\
\hline Dtee $(\mathrm{mm})$ & 72.5 \\
\hline $\mathrm{r}(\mathrm{mm})$ & 13 \\
\hline $\mathrm{Tf}(\mathrm{mm})$ & 9 \\
\hline Tw $(\mathrm{mm})$ & 6.5 \\
\hline
\end{tabular}




\section{PEMBAHASAN STUDI KASUS}

\section{Pendahuluan}

Penelitian ini akan menguji serangkaian kasus analisis pada balok kastela honeycomb 450x150 yang dibuat oleh PT. Gunung Garuda. Ukuran dan material yang digunakan dalam analisis akan disesuaikan dengan yang tertera di brosur spesifikasi. Proses Eigenvalue Buckling Analysis dan Nonlinear Analysis akan memberikan output berupa buckling load dan beban yang dapat dicapai oleh penampang dalam berbagai kasus serta displacement lateral dan vertikal dari kasus-kasus tersebut. Pengaruh residual stress diabaikan pada analisis ini. Pengaruh ketidaksempurnaan awal dan material nonlinearity diperhitungkan dalam analisis melalui parameter yang didefinisikan pada simulasi.

Balok kastela pada analisis ini akan dikerjakan dengan asumsi jenis perletakan pinned pada salah satu ujung dan roller pada ujung lainnya. Lateral restraint akan diberikan pada kedua ujung balok kastela untuk mencegah terjadinya displacement lateral dan efek twisting pada ujung balok. Skema tersebut dapat dilihat pada Gambar 3 hingga Gambar 5. Kasus analisis yang akan ditinjau dapat dilihat pada Gambar 6 dan 7. Titik pengukuran displacement ditentukan pada ujung flange tekan yang cenderung mengalami sedikit tarik pada flange atas di tengah bentang balok kastela.

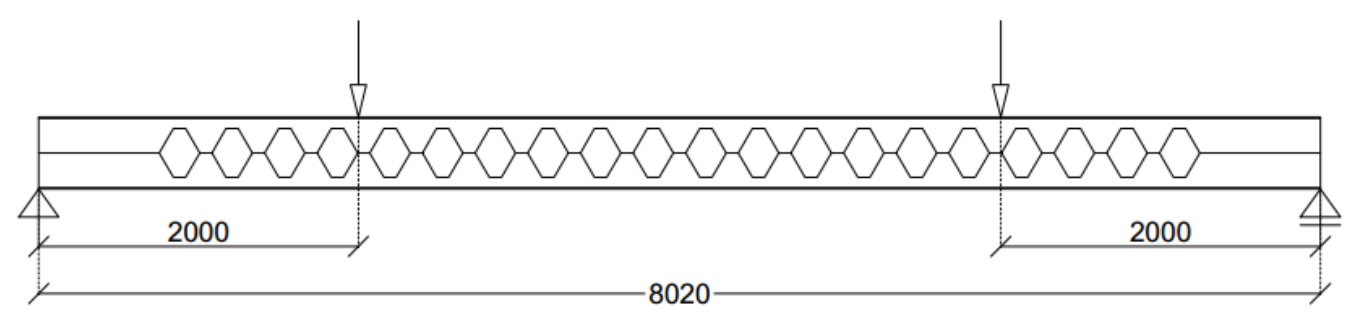

Gambar 3. Tampak Samping Skema Pembebanan Balok Kastela

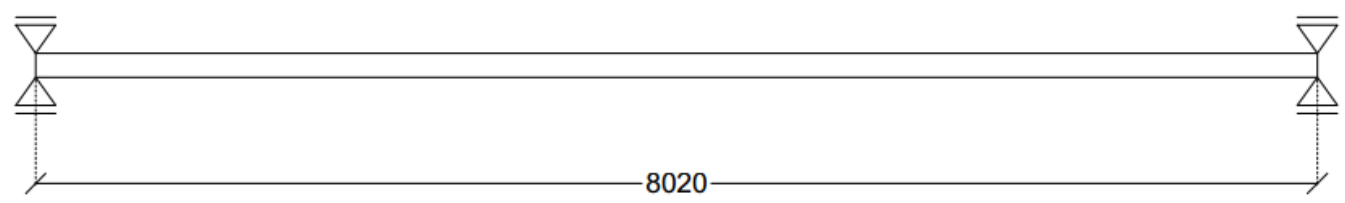

Gambar 4. Tampak Atas Skema Pembebanan Balok Kastela

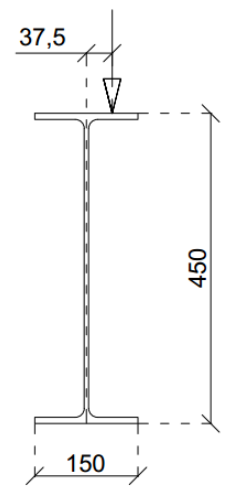

Gambar 5. Pembebanan Balok Kastela 

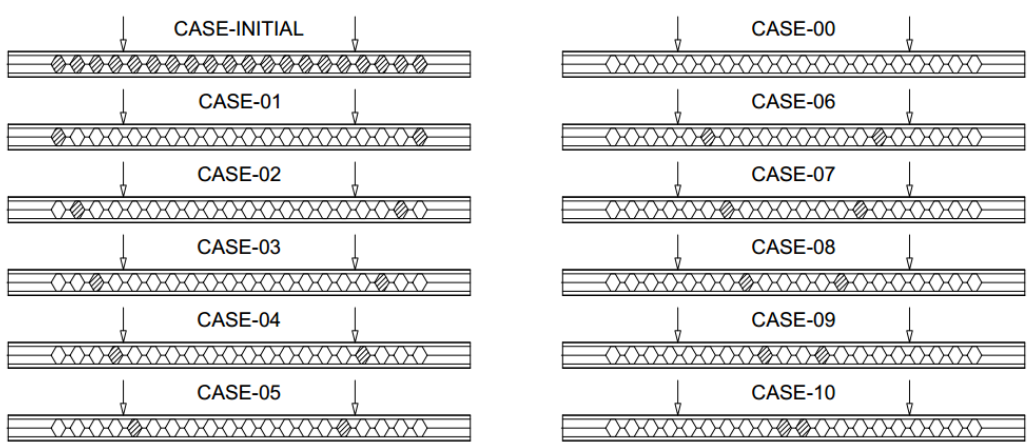

VIIIS = PENUTUPAN LUBANG

Gambar 6. Kasus Analisis (1 dari 2)
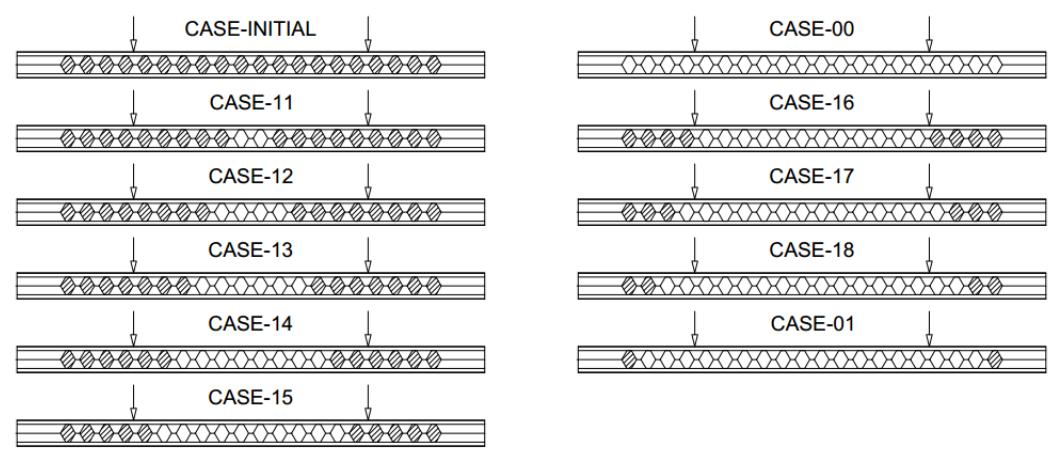

$=$ PENUTUPAN LUBANG

Gambar 7. Kasus Analisis (1 dari 2)

\section{Hasil Analisis}

Analisis yang telah dilakukan memberikan output berupa buckling load berdasarkan Eigenvalue Buckling Analysis dan actual load serta displacement baik pada arah lateral maupun vertikal berdasarkan Nonlinear Analysis. Hasil analisis tersebut dapat dilihat pada Gambar 8 hingga Gambar 13 dan Tabel 2.

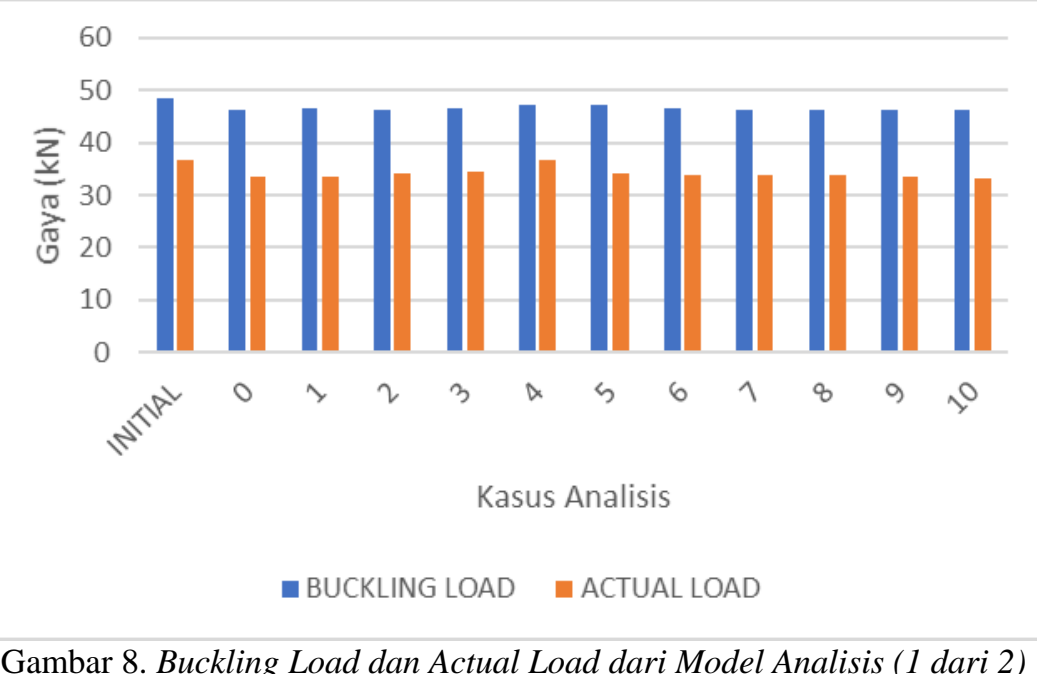




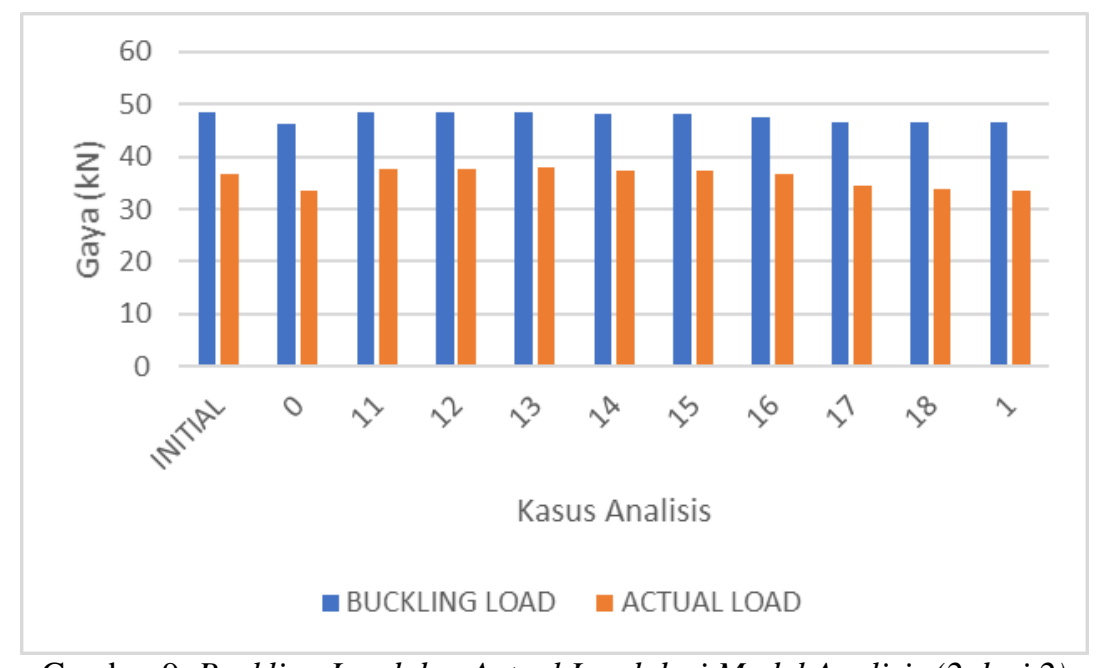

Gambar 9. Buckling Load dan Actual Load dari Model Analisis (2 dari 2)

Tabel 2. Buckling Load dan Actual Load Setiap Kasus Analisis

\begin{tabular}{|c|c|c|}
\hline CASE & $\begin{array}{c}\text { BUCKLING } \\
\text { LOAD }\end{array}$ & $\begin{array}{c}\text { ACTUAL } \\
\text { LOAD }\end{array}$ \\
\hline INITIAL & 48.59 & 36.75658576 \\
\hline 0 & 46.305 & 33.58135841 \\
\hline 1 & 46.438 & 33.61168509 \\
\hline 2 & 46.41 & 34.03171044 \\
\hline 3 & 46.493 & 34.56215231 \\
\hline 4 & 47.153 & 36.63797531 \\
\hline 5 & 47.141 & 34.08487578 \\
\hline 6 & 46.574 & 33.97102903 \\
\hline 7 & 46.409 & 33.92562873 \\
\hline 8 & 46.352 & 33.99761603 \\
\hline 9 & 46.327 & 33.53301139 \\
\hline 10 & 46.316 & 33.3257978 \\
\hline
\end{tabular}

\begin{tabular}{|c|c|c|}
\hline CASE & $\begin{array}{c}\text { BUCKLING } \\
\text { LOAD }\end{array}$ & $\begin{array}{c}\text { ACTUAL } \\
\text { LOAD }\end{array}$ \\
\hline 11 & 48.467 & 37.70767 \\
\hline 12 & 48.456 & 37.7041 \\
\hline 13 & 48.41 & 37.93485 \\
\hline 14 & 48.339 & 37.39515 \\
\hline 15 & 48.161 & 37.32954 \\
\hline 16 & 47.528 & 36.5756 \\
\hline 17 & 46.736 & 34.48874 \\
\hline 18 & 46.537 & 33.89038 \\
\hline
\end{tabular}

\section{GAYA VS DISPLACEMENT LATERAL}

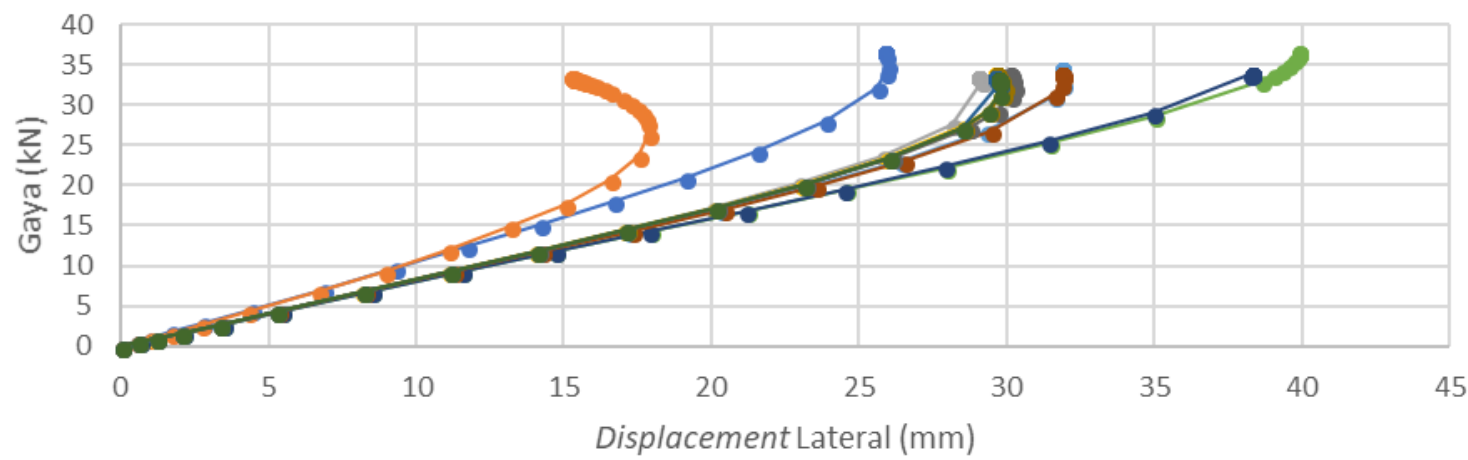

$\longrightarrow-$ INITIAL $\multimap 0 \multimap-1 \multimap-2 \multimap-3 \multimap-4 \rightarrow-5 \multimap-6 \multimap-7 \multimap-8 \rightarrow-9 \multimap 10$

Gambar 10. Kurva Gaya terhadap Displacement Lateral (1 dari 2) 


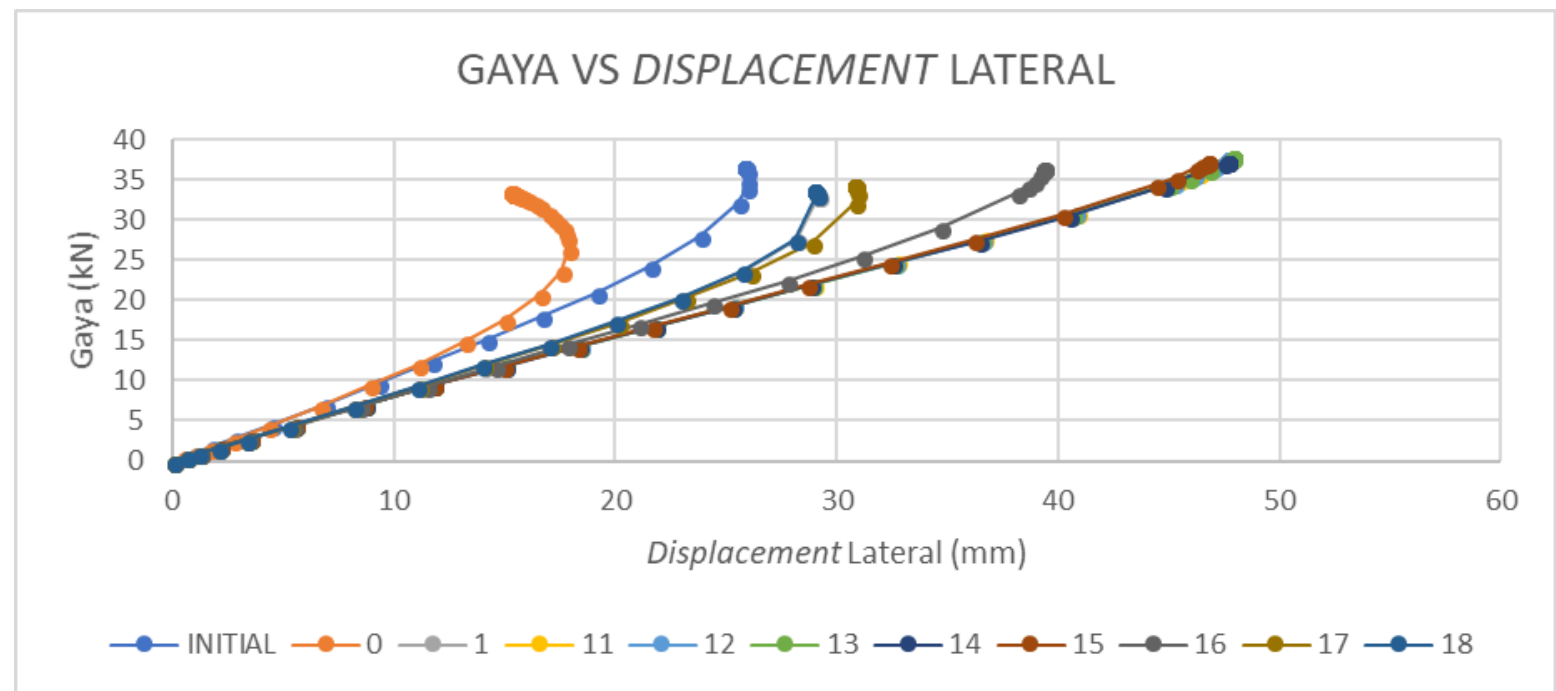

Gambar 11. Kurva Gaya terhadap Displacement Lateral (2 dari 2)

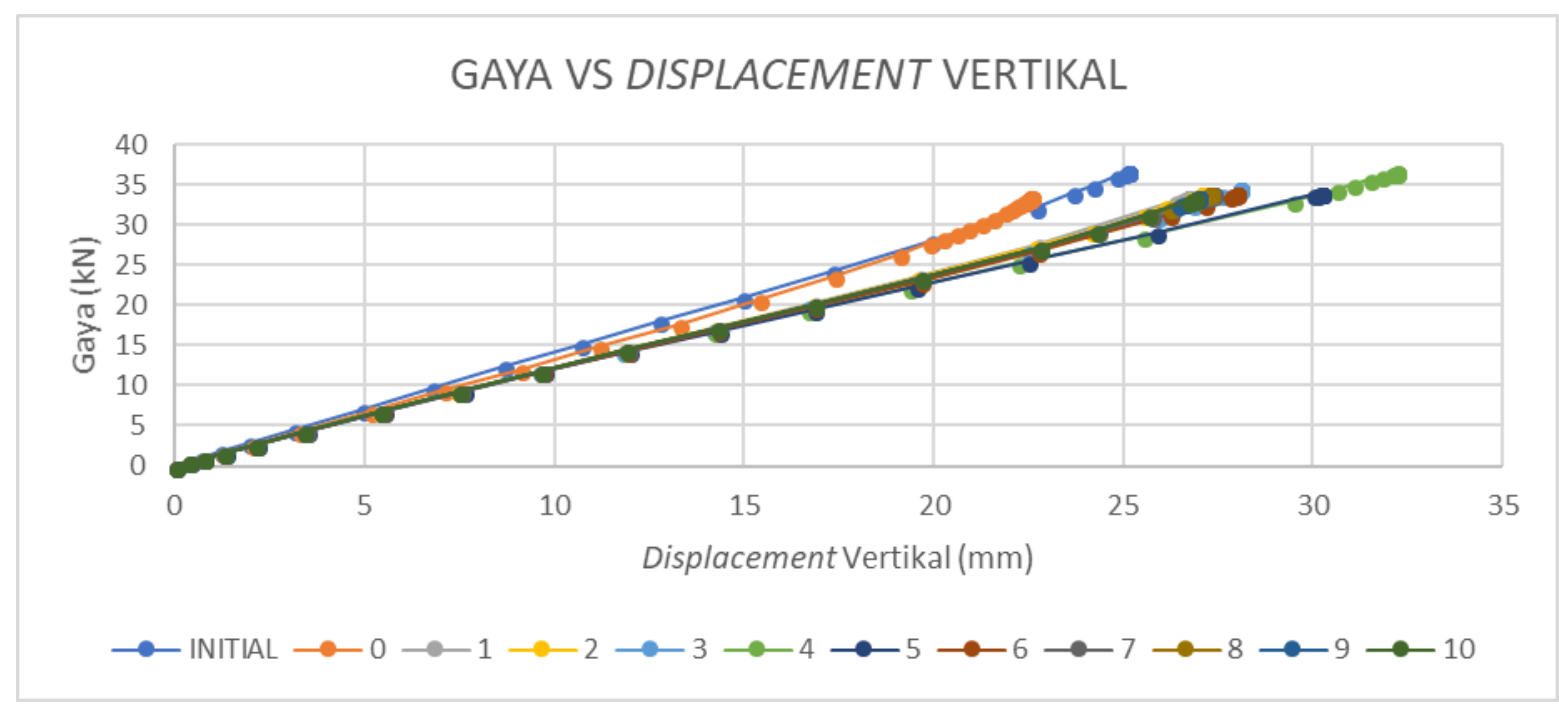

Gambar 12. Kurva Gaya terhadap Displacement Vertikal (1 dari 2)

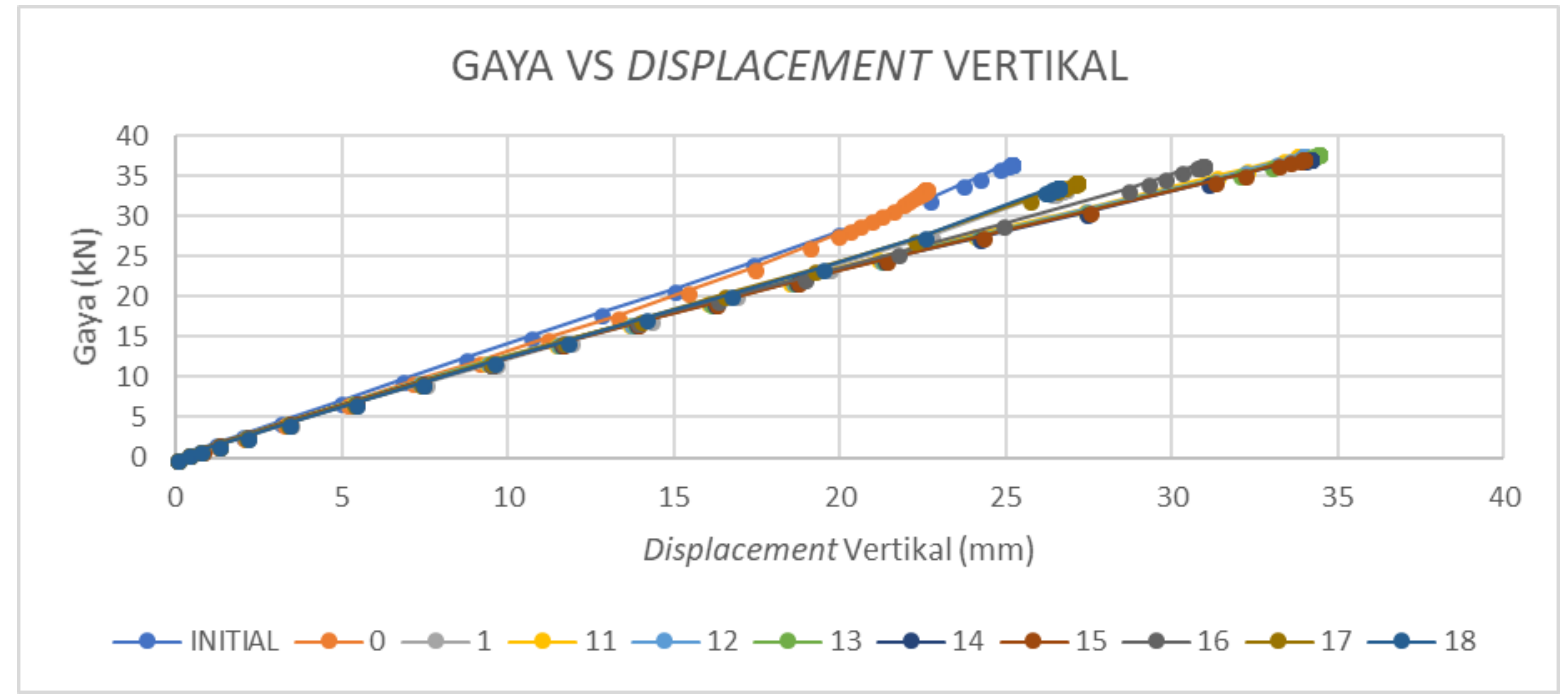

Gambar 13. Kurva Gaya terhadap Displacement Vertikal (2 dari 2) 


\section{Buckling Load}

Buckling load dan actual load mengalami perubahan nilai seiring dengan perubahan posisi penutupan lubang. Gambar 3 memberikan gambaran yang lebih jelas untuk memahami pengaruh perubahan lokasi lubang terhadap beban-beban tersebut. Peningkatan paling jelas terlihat pada kasus analisis 4 dimana lubang terdekat terhadap titik bekerjanya gaya ditutup. Apabila dibandingkan dengan kasus analisis 0 dimana tidak ada lubang yang ditutup, terjadi peningkatan buckling load sebesar $1.8313 \%$ dari $46.305 \mathrm{kN}$ menjadi $47.153 \mathrm{kN}$. Actual load mengalami peningkatan sebesar $9.1021 \%$ dari $33.58135 \mathrm{kN}$ menjadi $36.63795 \mathrm{kN}$.

Hasil yang serupa juga terjadi pada kasus analisis 5 dengan perubahan yang lebih kecil terhadap kasus analisis 0 . Buckling load mengalami peningkatan sebesar $1.8054 \%$ dari $46.305 \mathrm{kN}$ menjadi $47.141 \mathrm{kN}$. Actual load mengalami peningkatan sebesar $1.4993 \%$ dari $33.58135 \mathrm{kN}$ menjadi $34.08485 \mathrm{kN}$. Peningkatan gaya yang lebih kecil apabila dibandingkan dengan kasus analisis 4 dianggap wajar karena lubang yang ditutup pada kasus analisis 4 lebih dekat terhadap titik bekerjanya beban apabila dibandingkan dengan kasus analisis 5 .

Hasil analisis untuk kasus analisis 11 hingga 18 dapat dilihat pada Gambar 4. Kasus analisis 1, 18, dan 17 memberikan peningkatan kekuatan yang relatif lebih kecil apabila dibandingkan dengan kasus analisis $16,15.14$. 13. 12. dan 11. Sebagai contoh, kasus analisis 17 mengalami peningkatan buckling load sebesar $0.9308 \%$ dari $46.305 \mathrm{kN}$ menjadi $46.736 \mathrm{kN}$ dan actual load mengalami peningkatan sebesar $2.7021 \%$ dari $33.58135 \mathrm{kN}$ menjadi $34.48874 \mathrm{kN}$.

Tabel 3 memperlihatkan bahwa peningkatan actual load yang relatif besar antara kasus analisis 17 dan 16 . Seiring dengan semakin banyak lubang yang ditutup, peningkatan terhadap buckling load dan actual load tersebut mengalami penurunan (diminishing results) dan mulai terlihat pada perbandingan kasus analisis 16 terhadap 15 . Hal ini juga semakin didukung dengan perbandingan antara kasus analisis 15 terhadap kasus analisis 11, dimana selisih peningkatan buckling load hanya pada $0.6608 \%$ dan actual load pada $0.9756 \%$.

Tabel 3. Perbandingan Peningkatan Beban pada Beberapa Kasus

\begin{tabular}{|c|c|c|}
\hline $\begin{array}{c}\text { Kasus } \\
\text { Analisis }\end{array}$ & $\begin{array}{c}\text { Peningkatan Buckling Load } \\
\text { terhadap Kasus Initial }\end{array}$ & $\begin{array}{c}\text { Peningkatan Actual Load } \\
\text { terhadap Kasus Initial }\end{array}$ \\
\hline 17 & $0.9308 \%$ & $2.7021 \%$ \\
\hline 16 & $2.6412 \%$ & $8.9461 \%$ \\
\hline 15 & $4.0082 \%$ & $11.3119 \%$ \\
\hline 11 & $4.669 \%$ & $12.2875 \%$ \\
\hline
\end{tabular}

\section{Displacement Lateral dan Vertikal}

Berdasarkan Gambar 5 hingga Gambar 8, dapat dilihat bahwa penutupan lubang bukaan tidak memberikan peningkatan daya dukung yang signifikan. Displacement lateral dan vetikal maksimum akibat beban yang bekerja pada umumnya mengalami perubahan yang cukup seragam, yaitu pada rentang $11.276 \mathrm{~mm}$ hingga $14.033 \mathrm{~mm}$ untuk displacement lateral maksimum dan pada rentang $4.164 \mathrm{~mm}$ hingga $5.511 \mathrm{~mm}$ untuk displacement vertikal maksimum. Hal ini dapat dilihat pada hasil analisis kasus 1, 2, 3, 6, 7, 8, 9, 10, 17, dan 18.

Peningkatan terhadap daya dukung yang cukup signifikan terjadi setelah lubang bukaan di dekat titik gaya bekerja ditutup, seperti yang dapat dilihat pada hasil analisis kasus 4 dan 5. Kasus 11, 12, 13, 14, 15, dan 16 juga menunjukkan hal yang sama setelah lubang di dekat titik bekerjanya gaya ditutup. Namun hal ini juga diikuti dengan peningkatan displacement yang berada pada rentangan $20.419 \mathrm{~mm}$ hingga $30.001 \mathrm{~mm}$ untuk displacement lateral maksimum dan $7.665 \mathrm{~mm}$ hingga $11.802 \mathrm{~mm}$ untuk displacement vertikal maksimum. Tabel 3 dan 4 akan memperlihatkan besaran displacement yang terjadi dan perbandingannya terhadap kasus analisis 0 . 
Tabel 3. Perbandingan Displacement terhadap Kasus Analisis 0 (1 dari 2)

\begin{tabular}{|c|c|c|c|c|c|c|c|c|}
\hline CASE & \multicolumn{2}{|c|}{ U1 MAX } & \multicolumn{2}{c|}{ U1 FINAL } & \multicolumn{2}{c|}{ U2 MAX } & \multicolumn{2}{c|}{ U2 FINAL } \\
\hline INITIAL & 25.951 & - & 25.804 & - & 25.113 & - & 25.113 & - \\
\hline 0 & 17.860 & - & 15.209 & - & 22.538 & - & 22.538 & - \\
\hline 1 & 29.136 & $63.14 \%$ & 29.001 & $90.69 \%$ & 26.702 & $18.48 \%$ & 26.702 & $18.48 \%$ \\
\hline 2 & 29.809 & $66.90 \%$ & 29.583 & $94.51 \%$ & 27.054 & $20.04 \%$ & 27.053 & $20.04 \%$ \\
\hline 3 & 31.893 & $78.57 \%$ & 31.816 & $109.20 \%$ & 28.049 & $24.45 \%$ & 28.047 & $24.45 \%$ \\
\hline 4 & 39.856 & $123.16 \%$ & 39.856 & $162.06 \%$ & 32.176 & $42.76 \%$ & 32.176 & $42.76 \%$ \\
\hline 5 & 38.279 & $114.33 \%$ & 38.279 & $151.69 \%$ & 30.203 & $34.01 \%$ & 30.203 & $34.01 \%$ \\
\hline 6 & 31.851 & $78.34 \%$ & 31.835 & $109.32 \%$ & 27.959 & $24.05 \%$ & 27.959 & $24.05 \%$ \\
\hline 7 & 30.229 & $69.26 \%$ & 30.063 & $97.67 \%$ & 27.357 & $21.39 \%$ & 27.357 & $21.39 \%$ \\
\hline 8 & 29.879 & $67.30 \%$ & 29.639 & $94.88 \%$ & 27.261 & $20.96 \%$ & 27.261 & $20.96 \%$ \\
\hline 9 & 29.709 & $66.34 \%$ & 29.577 & $94.48 \%$ & 26.953 & $19.59 \%$ & 26.953 & $19.59 \%$ \\
\hline 10 & 29.736 & $66.50 \%$ & 29.672 & $95.10 \%$ & 26.849 & $19.13 \%$ & 26.849 & $19.13 \%$ \\
\hline
\end{tabular}

Tabel 4. Perbandingan Displacement terhadap Kasus Analisis 0 (2 dari 2)

\begin{tabular}{|c|c|c|c|c|c|c|c|c|}
\hline CASE & \multicolumn{2}{|c|}{ U1 MAX } & \multicolumn{2}{c|}{ U1 FINAL } & \multicolumn{2}{c|}{ U2 MAX } & \multicolumn{2}{c|}{ U2 FINAL } \\
\hline INITIAL & 25.951 & - & 25.804 & - & 25.113 & - & 25.113 & - \\
\hline 0 & 17.860 & - & 15.209 & - & 22.538 & - & 22.538 & - \\
\hline 11 & 47.617 & $166.61 \%$ & 47.617 & $213.09 \%$ & 33.741 & $49.71 \%$ & 33.741 & $49.71 \%$ \\
\hline 12 & 47.652 & $166.81 \%$ & 47.652 & $213.32 \%$ & 33.933 & $50.56 \%$ & 33.933 & $50.56 \%$ \\
\hline 13 & 47.861 & $167.98 \%$ & 47.861 & $214.69 \%$ & 34.340 & $52.37 \%$ & 34.340 & $52.37 \%$ \\
\hline 14 & 47.611 & $166.58 \%$ & 47.611 & $213.05 \%$ & 34.103 & $51.32 \%$ & 34.103 & $51.32 \%$ \\
\hline 15 & 46.719 & $161.58 \%$ & 46.719 & $207.18 \%$ & 33.909 & $50.46 \%$ & 33.909 & $50.46 \%$ \\
\hline 16 & 39.299 & $120.04 \%$ & 39.299 & $158.40 \%$ & 30.896 & $37.09 \%$ & 30.896 & $37.09 \%$ \\
\hline 17 & 30.873 & $72.86 \%$ & 30.762 & $102.27 \%$ & 27.101 & $20.25 \%$ & 27.101 & $20.25 \%$ \\
\hline 18 & 29.090 & $62.88 \%$ & 28.929 & $90.21 \%$ & 26.526 & $17.70 \%$ & 26.526 & $17.70 \%$ \\
\hline 1 & 29.136 & $63.14 \%$ & 29.001 & $90.69 \%$ & 26.702 & $18.48 \%$ & 26.702 & $18.48 \%$ \\
\hline
\end{tabular}

Pada analisis nonlinear yang dilakukan, ditemukan bahwa balok kastela tidak mengalami kelelehan pada bagian tengah bentangnya ketika analisis berakhir. Hal ini sejalan dengan fenomena elastic lateral-torsional buckling dimana balok mengalami fenomena buckling sebelum materialnya mengalami kelelehan (yielding).

\section{KESIMPULAN}

Berdasarkan analisis yang dilakukan terhadap lubang bukaan pada balok kastela terhadap defleksi dan lateraltorsional buckling yang terjadi, dapat disimpulkan bahwa:

1. Penutupan lubang menyebabkan peningkatan daya dukung yang relatif rendah, kecuali apabila lubang di dekat titik dimana gaya bekerja ditutup akan menyebabkan peningkatan actual load sebesar $9.1021 \%$ pada perbandingan kasus analisis 4 terhadap 0 .

2. Kurva hasil analisis menunjukkan bahwa apabila semua lubang kecuali lubang di tengah ditutup akan menyebabkan peningkatan displacement yang relatif besar pada arah lateral dan vertikal, pada kasus 11 terhadap kasus 0 menyebabkan peningkatan sebesar $166.61 \%$ untuk displacement lateral maksimum dari $17.86 \mathrm{~mm}$ menjadi $47.617 \mathrm{~mm}$ dan peningkatan sebesar $49.71 \%$ untuk displacement vertikal maksimum dari $22.538 \mathrm{~mm}$ menjadi $33.741 \mathrm{~mm}$.

3. Displacement pada arah lateral dan vertikal akan lebih kecil apabila semua lubang ditutup ataupun dibuka.

Berdasarkan penelitian yang telah dilakukan pada analisis ini, ada beberapa saran yang dapat dijadikan sebagai acuan untuk pelaksanaan penelitian berikutnya, yaitu:

1. mencoba simulasi dengan menggunakan second-order solid element seperti elemen C3D20, 
2. kasus analisis ditambahkan agar pengaruh jumlah bukaan lubang dapat mencakup lebih banyak kemungkinan,

3. mencoba simulasi dengan cara pembebanan lainnya, dan

4. memperhitungkan faktor residual stress ke dalam analisis.

\section{DAFTAR PUSTAKA}

Abaqus Analysis User's Guide (6.13). Dassault Systèmes, 2013.

American Institute of Steel Construction. AISC 360-10 - Specification for Structural Steel Buildings. Chicago: AISC, 2010.

—. AISC Design Guide 31 - Castellated and Cellular Beam Design. American Institute of Steel Construction, 2016.

ASTM International. ASTM A6 / A6M-07, Standard Specification for General Requirements for Rolled Structural Steel Bars, Plates, Shapes, and Sheet Piling. West Conshohocken, 2007.

Demirdjian, Sevak. Stability of Castellated Beam Webs. Thesis. McGill University. Montreal, 1999.

Sehwail, Mohammad Mofeed. Lateral Torsional Buckling of Steel I-Section Cellular. Thesis. Eastern Mediterranean University. Gazimağusa, 2013.

University of Colorado Boulder. "Advanced Finite Element Methods (ASEN 6367) Course Material." n.d. University of Colorado Boulder. Course Material. 27 Juni 2018.

Yun, Xiang and Leroy Gardner. "Stress-Strain Curves for Hot-Rolled Steel." Journal of Constructional Steel Research 133 (2017): 36-46. Journal Article. 